\title{
Comparison of knowledge, attitude, and practices of animal and human brucellosis between nomadic pastoralists and non- pastoralists in Kenya
}

M. Kariuki Njenga ${ }^{1}$, Eric Ogolla ${ }^{2} \mathbb{D}$, Samuel Mwangi Thumbi ${ }^{1}$, Isaac Ngere ${ }^{1}$, Sylvia Omulo ${ }^{1}$, Mathew Muturi ${ }^{3}$, Doris Marwanga ${ }^{4}$, Austine Bitek ${ }^{5}$, Bernard Bett ${ }^{6}$, Marc-Alain Widdowson ${ }^{7}$, Peninah Munyua ${ }^{7}$ and Eric Mogaka Osoro ${ }^{1 *}$

\begin{abstract}
Background: The seroprevalence of brucellosis among nomadic pastoralists and their livestock in arid lands is reported to be over10-fold higher than non-pastoralists farmers and their livestock in Kenya. Here, we compared the seroprevalence of nomadic pastoralists and mixed farming with their knowledge of the disease and high-risk practices associated with brucellosis infection.

Methods: Across-sectional study was conducted in two counties - Kiambu County where farmers primarily practice smallholder livestock production and crop farming, and Marsabit County where farmers practice nomadic pastoral livestock production. Stratified random sampling was applied, in which sublocations were initially selected based on predominant livestock production system, before selecting households using randomly generated geographical coordinates. In each household, up to three persons aged 5 years and above were randomly selected, consented, and tested for Brucella spp IgG antibodies. A structured questionnaire was administered to the household head and selected individuals on disease knowledge and risky practices among the pastoralists and mixed farmers compared. Multivariable mixed effects logistic regression model was used to assess independent practices associated with human Brucella spp. lgG seropositivity.

Results: While the majority (74\%) of pastoralist households had little to no formal education when compared to mixed (8\%), over 70\% of all households (pastoralists and mixed farmers) had heard of brucellosis and mentioned its clinical presentation in humans. However, fewer than 30\% of all participants (pastoralists and mixed farmers) knew how brucellosis is transmitted between animals and humans or how its transmission can be prevented. Despite their comparable knowledge, significantly more seropositive pastoralists compared to mixed farmers engaged in risky practices including consuming unboiled milk $(79.5 \%$ vs $1.7 \%, p<0.001)$ and raw blood $(28.3 \%$ vs $0.4 \%, p<0.001)$, assisting in animal birth (43.0\% vs 9.3\%, $p<0.001)$, and handling raw hides (30.6\% vs $5.5 \%, p<0.001)$.,

Conclusion: Nomadic pastoralists are more likely to engage in risky practices that promote Brucella Infection, probably because of their occupation and culture, despite having significant knowledge of the disease.
\end{abstract}

Keywords: Brucellosis, Knowledge, Risky practices, Kenya

\footnotetext{
* Correspondence: eric.osoro@wsu.edu

${ }^{1}$ Washington State University Global Health Program, Washington State

University, Nairobi, Kenya

Full list of author information is available at the end of the article
}

(c) The Author(s). 2020 Open Access This article is distributed under the terms of the Creative Commons Attribution 4.0 International License (http://creativecommons.org/licenses/by/4.0/), which permits unrestricted use, distribution, and reproduction in any medium, provided you give appropriate credit to the original author(s) and the source, provide a link to the Creative Commons license, and indicate if changes were made. The Creative Commons Public Domain Dedication waiver (http://creativecommons.org/publicdomain/zero/1.0/) applies to the data made available in this article, unless otherwise stated. 


\section{Background}

Brucellosis is a globally widespread zoonotic disease that causes substantial morbidity in both livestock and human populations, particularly in Latin America, Middle East, and Africa where it is endemic [1]. Of the six species of the bacteria, Brucella abortus and Brucella melitensis are the predominant species associated with human disease. These Brucella species are transmitted from infected animals primarily through inhalation of the bacteria, consumption of contaminated unpasteurized dairy products, and direct contact with infected animal fluids and tissues $[1,2]$. While the disease is rarely fatal, human brucellosis is a chronic debilitating and disabling disease that is often difficult to diagnose and requires long and expensive antibiotic treatment, which may not always be successful $[3,4]$. Among livestock (cattle, sheep, goats and camels), $B$. abortus and B. melitensis are spread through contact with infected birthing tissues and fluids via ingestion or direct contact with mucous membranes and sexually [1, 2]. Brucellosis infection in livestock is often chronic, leads to abortions and infertility and is associated with major economic losses associated with reduced productivity in animals, and trade restrictions [5].

In endemic countries, the seroprevalence of brucellosis in livestock varies from $<1$ to $30 \%$ [6-10]. In these regions, human incidence of the disease ranges widely, with areas such as Africa and Middle East reporting between 50 and 250 cases per 100,000 [3]. Most data show human seroprevalence of brucellosis is positively correlated with livestock seroprevalence, emphasizing the role of livestock as the source of human infections [3]. Public education in combination with livestock vaccination has been shown to reduce disease incidence in humans and animal populations through adoption of risk reduction practices [11]. Interestingly, many studies show significant knowledge of brucellosis among rural and urban populations in developing countries; with between 40 and 100\% of populations reporting awareness of the disease and its clinical presentations [8, 12-14]. However, few studies have been carried out among nomadic pastoralist communities residing in underdeveloped remote and arid areas and deriving livelihood primarily from rearing livestockwhere infection risk is likely elevated $[13,15]$.

In Africa, over 100 million nomadic pastoralists, living in the underserved arid and semi-arid lands of the continents own more than $30 \%$ of all livestock and $50 \%$ of small ruminants, supplying $60 \%$ of beef and $40 \%$ of sheep and goat meat in the countries where they inhabit (FAO, 2012). In 2013, a study in Kenya reported a 12fold higher seroprevalence of brucellosis among nomadic pastoralist livestock herds in northern Kenya compared to mixed farmers (livestock and crops) in central Kenya, and 14-fold higher prevalence in pastoralist households (humans) when compared to mixed farmers [10].
Similarly, the livestock prevalence (cattle, sheep, goats and camels) was 11-fold higher and human prevalence 19-fold higher among pastoralists when compared to mixed farmers. A breakdown of the seroprevalence among livestock species gave a range of $11-16 \%$ prevalence in pastoral livestock, compared to $0.8-2.4 \%$ in livestock reared in small-scale production systems [10].

Here, we compared the knowledge of brucellosis and risky practices of infection among seropositive households in two communities; nomadic pastoralists living in the remote, underdeveloped and arid northern region, and mixed farmers living in a developed, high potential, agro-ecological region of Kenya.

\section{Methods}

\section{Study design and sample size determination}

A cross sectional study compared knowledge and practices related to brucellosis between participants from the predominantly nomadic pastoralists of Marsabit County and that of mixed farmers of Kiambu County (Fig. 1). Kiambu County neighbors Nairobi, the capital city of Kenya, and is located in a high potential agro-ecological zone with farmers practicing smallholder livestock production (keeping primarily cattle, sheep and goats) and crop farming. Marsabit County is located in the northern arid agro-ecological zone of the country and farmers practice nomadic pastoral livestock production mainly, keeping cattle, sheep, goats and camels. The estimated livestock population in Marsabit County is 2,731,407, of which $42 \%$ are goats, $35 \%$ are sheep, $16 \%$ are cattle and $7 \%$ are camels; whereas Kiambu County has a livestock population of $1,832,045$ of which $39 \%$ are sheep, $38 \%$ are goats, $22 \%$ cattle and $<1 \%$ camels.

Kiambu County has good physical infrastructure with $35 \%$ of the roads tarmacked or on gravel, accessible medical and veterinary services, and is densely populated with over 630 persons per square kilometer, inhabited by a community with high literacy levels, more than $45 \%$ of them deriving livelihood from the Capital City of Nairobi [16]. In contrast, Marsabit County has only one major road with most areas inaccessible for medical or veterinary services and is sparsely populated with 4 persons per square kilometer, inhabited by a poor, nomadic pastoralist communities that derive their livelihood from rearing livestock, including cattle sheep, goats, and camels [17].

This study was part of a larger study on seroprevalence of and risk factors for brucellosis infection in humans and livestock in Kenya whose findings were published previously [10]. The sample size was calculated based on an estimated Brucella spp. seroprevalence of 5\% in Kiambu County and 50\% in Marsabit County, with an error margin of 2 and 5\%, respectively, at 95\% confidence level. A design effect of two and a factor of $10 \%$ 


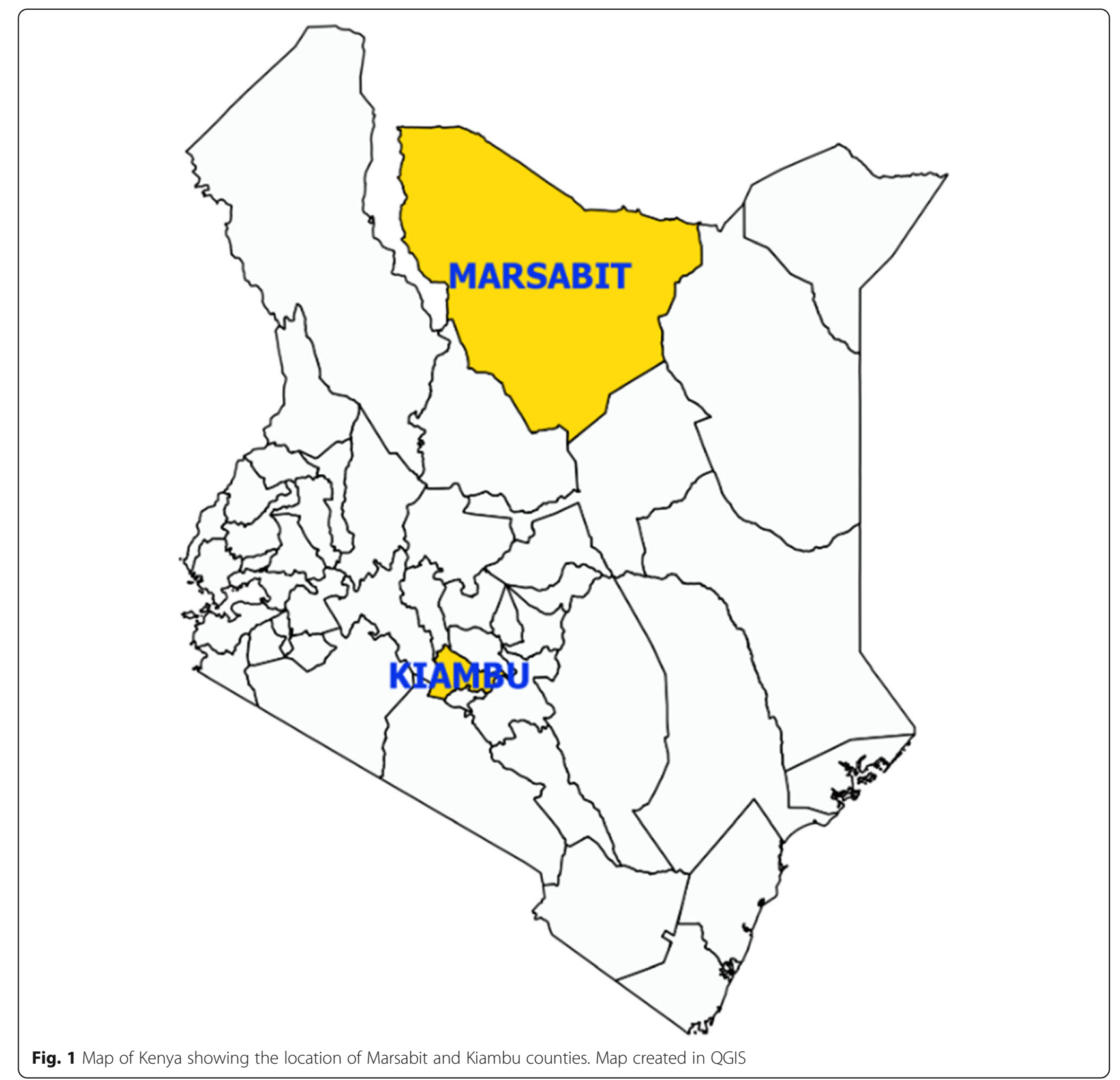

were applied to account for clustering and non-response respectively, giving a minimum sample size of 730 individuals for Marsabit and 866 individuals for Kiambu counties.

\section{Household selection and sampling}

The study applied stratified random sampling to identify study households in each county [10]. In the first stage, sub-locations were stratified by predominant livestock production system and $10 \%$ of sub-locations were randomly selected from each stratum in each county. This resulted in 21 sub-locations in Kiambu County and 10 in Marsabit County. In the second stage, the number of households to be visited in each sub-location were determined proportionate to the total human population and assuming an enrolment of three persons per household. In order to identify households to recruit into the study, random geographical coordinates were generated using ArcGIS corresponding to number of households for each sublocation. The selected household coordinates were loaded into a global positioning system device used by each study team. When the coordinates did not correspond to a household, the nearest household was visited. In each household, up to three persons aged 5 years and above were randomly selected, consented/assented in line with the ethical approval, and a structured 
questionnaire, loaded on to a smartphone, administered to each participant and the household head. Nomadic pastoralists were defined as households whose livelihood was based primarily on domesticated livestock production and involved seasonal movement of dwelling. Mixed farming were households whose livelihoods depended on both livestock rearing and crop farming.

\section{Data and sample collection and laboratory testing}

We used an electronic interviewer administered structured questionnaire with standardized questions and scheme to collect data from household respondents on knowledge and practices that may be associated with increased risk of infection with Brucella spp. The questionnaire was pretested, and interviewers trained before data collection. The data collected included knowledge of human and animal brucellosis including transmission, symptoms and modes of prevention. The study also collected data on practices at individual level including drinking of unboiled milk, assisting in animal birthing, drinking raw blood, working with raw hides and skins. Weekly frequencies on selected variables were done to check on data quality. A blood sample was collected from all eligible persons and animals as previously reported [10]. After processing for sera, the specimens were tested for presence of anti-Brucella spp. IgG antibodies using IBL-America IgG enzyme-linked immunosorbent assay (ELISA) and Svanova Biotech AB ELISA kits for human and animal samples respectively as we previously reported [10].

\section{Data analysis}

Data were analysed using $\mathrm{R}$ statistical software, version 3.5.1 [18]. Categorical variables were presented as percentages and their associations assessed by Chi-square test while continuous variables were tested using the ttest. Knowledge on human and animal brucellosis by household heads was presented by production system practiced by the household (nomadic pastoralism vs mixed farming).

The prevalence of practices among participants from households practicing nomadic pastoralism or mixed farming was compared. We conducted a multivariable mixed effects logistic regression model with human Brucella spp. IgG seropositivity as the outcome variable and included the practices, sex, age, and education level as predictor variables. Household was included in the model as a random effect to account for possible clustering. $P$-values $<0.05$ were considered significant. Missing values were excluded from the analysis and a goodnessof-fit test was conducted on the model using HosmerLemeshow test $(p>0.05)$.

\section{Ethical approval}

The study received ethical approval by the Kenya Medical Research Institute Scientific Ethical Review Committee (No. 2193) and Centers for Disease Control and Prevention Institutional Review Board. Project approval was also obtained from the Kenya Ministry of Health, and the Ministry of Agriculture Livestock and Fisheries.

\section{Results}

\section{Enrolled households and demographic data for} household heads

A total of 787 households were enrolled, of which 510 (65\%) were from Kiambu and 277 (35\%) from Marsabit. There were significantly more female household head respondents $(57.3 \%)$ in Kiambu than Marsabit County $(49.7 \%)(p<0.001)$. The average age of household heads respondents was 36.7 years (SD 19.2, range $=5-96$ ) in Kiambu, and 34.4 years (SD 19.9, range $=5-90)$ in Marsabit.

Of 787 enrolled households, $47 \%(n=371)$ reported practicing mixed farming, 26\% $(n=204)$ nomadic pastoralism, $4 \%(n=35)$ peri-urban livestock farming with no crops or movement, 21\% $(n=169)$ did not own any livestock and $1 \%(n=8)$ had missing data. Nearly all the nomadic pastoralists (96.1\%) were from Marsabit County while $92.2 \%$ of households practicing mixed farming were from Kiambu County (Table 1). Our subsequent analyses on knowledge and practices were based on 575 (73\%) households, which either practiced nomadic pastoralism or mixed farming.

\section{Knowledge of brucellosis disease among household heads}

Overall, about $84 \%$ of the household heads had heard about brucellosis and about 90\% knew it affected humans from among households practicing nomadic pastoralism or mixed farming. The majority $(76 \%)$ of the respondents reported knowledge of chills as a symptom with about one-third reporting at least one prevention method of or transmission method of human brucellosis (Table 1).

On knowledge of disease, $83.8 \%(n=204)$ of nomadic pastoralists and $83.5 \%(n=371)$ of mixed farmers had heard of brucellosis. Less than half of the participants from each of the two groups (31.0\% among nomadic pastoralists and $39.9 \%$ in mixed farmers, $p<0.001$ ) knew that the disease affected animals, and less than $20 \%$ could list at least one clinical sign in animals including abortion, swollen joints or reduced milk production. On disease transmission, less than $5 \%$ of participants from the two groups mentioned consuming raw dairy products or contact with aborted fetuses, as mechanisms of animal-tohuman transmission, whereas less than $30 \%$ of participants $(24.5 \%$ in nomadic pastoralists; $25.5 \%$ in mixed farmers) mentioned contamination with pastures or contact with wildlife as mechanisms of livestock transmission. Similarly, less than $30 \%$ of participants from the two 
Table 1 Knowledge of human brucellosis among household heads from nomadic pastoralists and mixed farming households, 2012-2013

\begin{tabular}{|c|c|c|c|c|c|}
\hline \multirow[t]{2}{*}{ Variable } & \multirow[t]{2}{*}{ Category } & \multirow{2}{*}{$\begin{array}{l}\text { Total } \\
\text { n (\%) }\end{array}$} & \multirow{2}{*}{$\begin{array}{l}\text { Nomadic Pastoralists } \\
\mathrm{n}(\%)\end{array}$} & \multirow{2}{*}{$\begin{array}{l}\text { Mixed Farmers } \\
\mathrm{n}(\%)\end{array}$} & \multirow[t]{2}{*}{$P$-value } \\
\hline & & & & & \\
\hline Total households & & $575(100.0)$ & $204(35.5)$ & $371(64.5)$ & \\
\hline \multirow[t]{2}{*}{ County } & Kiambu & $350(60.9)$ & $8(3.92)$ & $342(92.2)$ & $<0.001$ \\
\hline & Marsabit & $225(39.1)$ & $196(96.1)$ & $29(7.82)$ & \\
\hline \multirow[t]{2}{*}{ Heard of brucellosis ${ }^{a}$} & Yes & 479 (83.6) & $171(83.8)$ & $308(83.5)$ & 0.874 \\
\hline & No & $89(15.5)$ & $32(15.7)$ & $57(15.4)$ & \\
\hline \multirow[t]{3}{*}{ Are humans affected by brucellosis ${ }^{a}$} & Yes & $431(89.0)$ & $148(86.0)$ & $283(90.7)$ & 0.073 \\
\hline & No & $11(2.3)$ & $7(4.07)$ & $4(1.28)$ & \\
\hline & Don't know & $42(8.7)$ & $17(9.9)$ & $25(8.01)$ & \\
\hline \multirow[t]{7}{*}{ How do humans get brucellosis? } & $\begin{array}{l}\text { Eating uncooked/ undercooked } \\
\text { meat from an infected animal }\end{array}$ & $90(15.7)$ & $11(5.4)$ & $79(21.4)$ & $<0.001$ \\
\hline & Milking & $59(10.3)$ & $6(3.0)$ & $53(14.4)$ & $<0.001$ \\
\hline & Drinking/eating raw dairy products & $26(4.5)$ & $3(1.5)$ & $23(6.2)$ & 0.016 \\
\hline & Contact with aborted animal fetus & $13(2.3)$ & $4(2.0)$ & $9(2.4)$ & 0.76 \\
\hline & Herding & $10(1.75)$ & $0(0.0)$ & $10(2.7)$ & 0.017 \\
\hline & Slaughtering animals & $4(0.7)$ & $0(0.0)$ & $4(1.1)$ & 0.304 \\
\hline & Don't know & $146(25.5)$ & $68(33.3)$ & $78(21.1)$ & 0.003 \\
\hline \multirow[t]{4}{*}{ Signs and symptoms of brucellosis } & Chills & $437(76.3)$ & $83(40.7)$ & $354(95.9)$ & $<0.001$ \\
\hline & Lack of appetite & $195(34.0)$ & $163(79.9)$ & $32(8.67)$ & $<0.001$ \\
\hline & Joint pains & $102(17.8)$ & $94(46.1)$ & $8(2.2)$ & $<0.001$ \\
\hline & Fatigue & $76(13.3)$ & $74(36.3)$ & $2(0.5)$ & $<0.001$ \\
\hline \multirow[t]{4}{*}{ How is brucellosis prevented? } & Boiling milk & $104(18.2)$ & $8(3.9)$ & $96(26.0)$ & $<0.001$ \\
\hline & Medication & $54(9.4)$ & $26(12.7)$ & $28(7.6)$ & 0.058 \\
\hline & Vaccination & $15(2.6)$ & $0(0.0)$ & $15(4.1)$ & 0.01 \\
\hline & Other methods & $26(4.5)$ & $5(2.5)$ & $21(5.7)$ & 0.115 \\
\hline
\end{tabular}

${ }^{a}$ Variable has some missing data

groups knew how to prevent the disease in humans or animals including measures such as boiling milk (3.9\% among nomadic pastoralists vs $26.0 \%$ among mixed farmers, $p<0.001$ ) (Tables 1 and 2).

\section{Practices associated with Brucella spp. IgG seropositivity among mixed farmers and nomadic pastoralists}

From the 787 enrolled households, 1255 participants were recruited from Kiambu County (an average of 2.5 participant/household) and 765 from Marsabit County (an average of 2.8 participants per household). For this analysis, 562 participants from households practicing nomadic pastoralism and 982 participants from mixed farming households were included. A majority (74.0\%) of participants from nomadic pastoralist households had no formal education with only $5.1 \%$ completing secondary education or higher. In contrast, only $7.8 \%$ of participants from mixed farming household had no formal education with $47.5 \%$ completing secondary education or higher (Table 3).

Apart from routine livestock husbandry practices such as feeding and cleaning animal barns, we compared cultural and occupational practices associated with Brucella spp. IgG seropositivity between enrolled household members from mixed farming and nomadic pastoralist households. The practices assessed were drinking unboiled milk, drinking raw blood, assisting animals during birth, and handling raw hides.

More than $79 \%$ of nomadic pastoralists consumed unboiled milk when compared to $1.7 \%$ of the mixed farmers $(p<0.001)$, and $28.3 \%$ of nomadic pastoralists consumed raw blood compared to $0.4 \%$ among mixed farmers $(p<0.001)$. In addition, up to $43 \%$ of nomadic pastoralists assisted in animal birth or handled raw hides when compared to less than $10 \%$ among mixed farmers $(p<0.001)$ (Table 3).

\section{Association between practices and Brucella lgG sero- positivity}

In the bivariate analyses, consuming raw blood or unboiled milk, assisting animals in birth, nomadic pastoralism, and handling livestock hides were significantly associated with brucellosis seropositivity (Table 4). 
Table 2 Knowledge of animal brucellosis among household heads from nomadic pastoralists and mixed farming households, 2012-2013

\begin{tabular}{|c|c|c|c|c|c|}
\hline \multirow[t]{2}{*}{ Variable } & \multirow[t]{2}{*}{ Category } & \multirow{2}{*}{$\begin{array}{l}\text { Total } \\
\text { n (\%) }\end{array}$} & \multirow{2}{*}{$\begin{array}{l}\text { Nomadic Pastoralists } \\
\mathrm{n}(\%)\end{array}$} & \multirow{2}{*}{$\begin{array}{l}\text { Mixed Farmers } \\
\text { n (\%) }\end{array}$} & \multirow[t]{2}{*}{$P$-value } \\
\hline & & & & & \\
\hline Total households & & $575(100.0)$ & $204(35.5)$ & $371(64.5)$ & \\
\hline \multirow[t]{3}{*}{ Are animals affected? } & Yes & $176(36.7)$ & $53(31.0)$ & $123(39.9)$ & $<0.001$ \\
\hline & No & $118(24.6)$ & $61(35.7)$ & $57(18.5)$ & \\
\hline & Don't Know & $185(38.6)$ & $57(33.3)$ & $128(41.6)$ & \\
\hline \multirow[t]{4}{*}{ Which animals are affected? } & Cattle & $164(28.6)$ & $33(16.2)$ & $131(35.5)$ & $<0.001$ \\
\hline & Goats & $116(20.2)$ & $60(29.4)$ & $56(15.2)$ & $<0.001$ \\
\hline & Sheep & $74(12.9)$ & $31(15.2)$ & $43(11.7)$ & 0.251 \\
\hline & Camels & $26(4.5)$ & $19(9.3)$ & $7(1.9)$ & $<0.001$ \\
\hline \multirow[t]{4}{*}{ How brucellosis spread among animals? } & Ingestion of contaminated pasture & $3(0.5)$ & $52(25.5)$ & $91(24.5)$ & 0.226 \\
\hline & Sexually & $3(0.5)$ & $1(0.5)$ & $11(3.0)$ & 0.064 \\
\hline & Contact with wild animals & $1(0.2)$ & $3(1.5)$ & $4(1.1)$ & 0.697 \\
\hline & Others & $314(54.8)$ & $91(44.6)$ & $147(39.8)$ & 0.307 \\
\hline \multirow[t]{7}{*}{ Signs and symptoms of brucellosis? } & Abortion & $53(9.3)$ & 38 (18.6) & $15(4.1)$ & $<0.001$ \\
\hline & Swollen joints & $33(5.8)$ & $30(14.7)$ & $3(0.8)$ & $<0.001$ \\
\hline & Reduced milk production & $23(4.0)$ & $1(0.49)$ & $22(5.96)$ & 0.003 \\
\hline & Swollen testes & $3(0.5)$ & $0(0.0)$ & $3(0.8)$ & 0.556 \\
\hline & Infertility & $3(0.5)$ & $1(0.5)$ & $2(0.5)$ & 1 \\
\hline & Retained placenta & $1(0.2)$ & $1(0.5)$ & $0(0.0)$ & 0.356 \\
\hline & Don't know & $314(58.8)$ & $76(37.3)$ & $238(64.5)$ & $<0.001$ \\
\hline \multirow[t]{4}{*}{ How can brucellosis be prevented? } & Drug treatment & $70(12.2)$ & $33(16.2)$ & $37(10.0)$ & 0.043 \\
\hline & Vaccination & $57(10.0)$ & $13(6.4)$ & $44(11.9)$ & 0.048 \\
\hline & Slaughter & $2(0.4)$ & $2(1.0)$ & $0(0.0)$ & 0.126 \\
\hline & Don't know & $287(50.1)$ & 95 (46.6) & $192(52.0)$ & 0.244 \\
\hline
\end{tabular}

${ }^{a}$ Variable has some missing data

Among participants who were seropositive for Brucella spp., $68 \%$ reported consuming unboiled milk compared to $14.6 \%$ who drank unboiled milk and were seronegative $(\mathrm{cOR}[95 \% \mathrm{CI}]=12.5[9.6-16.4])$, whereas $24.6 \%$ reported consuming raw blood and were seropositive compared to $5.3 \%$ of those reported consuming raw blood and were seronegative $(\mathrm{cOR}[95 \% \mathrm{CI}]=5.8[4.2-$ 8.0]. Similarly, $42 \%$ of participants reported assisting in animal births and were seropositive compared to $17 \%$ who assisted in birthing but were seronegative $(\mathrm{cOR}[95 \% \mathrm{CI}]=3.6[2.7-4.9]$ (Table 4). The multivariate mixed effects logistic regression model identified drinking unboiled milk and being from a household that practiced nomadic pastoralism as independent risk practices associated with Brucella spp. IgG seropositivity. The odds of brucellosis seropositivity were 8 -fold higher among nomadic pastoralists compared to mixed farmers, $(\mathrm{aOR}[95 \% \mathrm{CI}]=8.6[3.6-20.2])$, after adjusting for other practices and sociodemographic characteristics (Table 4). Participants having formal education was a protective factor against Brucella spp. seropositivity.

\section{Discussion}

An important finding in this study was that whereas over $70 \%$ of both nomadic pastoralists and mixed farmers had heard of brucellosis disease and had knowledge of common symptom (chills and loss of appetite), less than $10 \%$ could identify key risky practices associated with brucellosis infection in humans including consuming raw dairy products and contact with aborted fetuses. Despite these comparable levels of knowledge of the disease among the two communities, over two-thirds of nomadic pastoralists engaged in risky practices including consumption of unboiled milk and raw blood, assisting with animal birth and handling raw hides. In contrast, less than $10 \%$ of mixed farmers engaged in these practices, including about $2 \%$ in consumption of unboiled milk or raw blood. Our findings show a strong link between these practices and Brucella spp. seropositivity, including a nearly 3 -fold higher odds of seropositivity for people who consumed unboiled milk. These practices combined with the high brucellosis seroprevalence (13.5\%) among their livestock, predisposes nomadic pastoralists to high Brucella spp. sero-positivity. 
Table 3 Comparison of demographic characteristics and practices that promote brucellosis infection between nomadic pastoralists and mixed farmers, 2012-2013

\begin{tabular}{|c|c|c|c|c|}
\hline \multirow[t]{2}{*}{ Variable } & \multirow[t]{2}{*}{ Category } & \multirow{2}{*}{$\begin{array}{l}\text { Nomadic Pastoralists }{ }^{\mathrm{a}}(N=562) \\
\mathrm{n}(\%)\end{array}$} & \multirow{2}{*}{$\begin{array}{l}\text { Mixed Farmers }{ }^{\mathrm{a}}(N=982) \\
\mathrm{n}(\%)\end{array}$} & \multirow[t]{2}{*}{$P$-value } \\
\hline & & & & \\
\hline \multirow[t]{2}{*}{ Sex } & Female & $277(49.3)$ & $546(55.6)$ & 0.019 \\
\hline & Male & $285(50.7)$ & $436(44.4)$ & \\
\hline Age, years & Mean (SD) & $34.4(19.7)$ & $37.6(20.3)$ & 0.003 \\
\hline \multirow[t]{4}{*}{ Education Level completed ${ }^{\mathrm{b}}$} & No Formal Education & $412(74.0)$ & $76(7.8)$ & $<0.001$ \\
\hline & Primary & $117(21.0)$ & $438(44.7)$ & \\
\hline & Secondary & $21(3.8)$ & $354(36.2)$ & \\
\hline & Post secondary & $7(1.3)$ & $111(11.3)$ & \\
\hline \multirow[t]{2}{*}{ Drink Unboiled Milk ${ }^{\mathrm{b}}$} & Yes & $418(79.5)$ & $16(1.7)$ & $<0.001$ \\
\hline & No & $108(20.5)$ & $946(98.3)$ & \\
\hline \multirow[t]{2}{*}{ Drink Raw Blood } & Yes & $159(28.3)$ & $4(0.4)$ & $<0.001$ \\
\hline & No & $403(71.7)$ & $978(99.6)$ & \\
\hline \multirow[t]{2}{*}{ Assist in Animal Birthing ${ }^{b}$} & Yes & $186(43.0)$ & $69(9.3)$ & $<0.001$ \\
\hline & No & $247(57.0)$ & $670(90.7)$ & \\
\hline \multirow[t]{2}{*}{ Handle Raw Hides } & Yes & $172(30.6)$ & $54(5.5)$ & $<0.001$ \\
\hline & No & $390(69.4)$ & $928(94.5)$ & \\
\hline \multirow[t]{2}{*}{ Clean Barns } & Yes & $416(74.0)$ & $635(64.7)$ & $<0.001$ \\
\hline & No & $146(26.0)$ & $347(35.3)$ & \\
\hline
\end{tabular}

${ }^{a}$ Includes participants from households that practiced either pastoralism or mixed farming

bariable has missing values

Table 4 Bivariable and multivariable mixed effects logistic regression for the association between participant demographic characteristics and practices and Brucella spp. seropositivity, 2012-2013

\begin{tabular}{|c|c|c|c|c|c|}
\hline \multirow[t]{2}{*}{ Variable } & \multirow[t]{2}{*}{ Category } & \multicolumn{2}{|c|}{ Brucella spp. seropositivity } & \multirow{2}{*}{$\begin{array}{l}\text { Bivariable analysis } \\
\text { Crude OR ( } 95 \% \mathrm{Cl})\end{array}$} & \multirow{2}{*}{$\begin{array}{l}\text { Multivariable mixed effects logistic model } \\
\text { Adjusted OR }(95 \% \mathrm{Cl})\end{array}$} \\
\hline & & Positive & Negative & & \\
\hline \multirow[t]{2}{*}{ Sex } & Male & $191(53.5)$ & $719(43.7)$ & $1.5(1.2-1.9)$ & $1.46(1.0-2.2)$ \\
\hline & Female & $166(46.5)$ & $928(56.3)$ & ref $f^{\beta}$ & ref $f^{\beta}$ \\
\hline Age, years & Mean (SD) & $37.8(19.9)$ & $35.3(19.4)$ & $1.0(1.0-1.0)$ & $1.0(1.0-1.0)$ \\
\hline \multirow[t]{4}{*}{ Highest education level completed } & Primary & $75(21.1)$ & $682(41.6)$ & $0.1(0.1-0.2)$ & $0.5(0.3-1.0)$ \\
\hline & Secondary & $16(4.5)$ & $489(29.8)$ & $<0.1(<0.1-0.1)$ & $0.2(0.1-0.6)$ \\
\hline & Post secondary & $4(1.12)$ & $163(9.9)$ & $<0.1(<0.1-0.1)$ & $0.4(0.1-1.5)$ \\
\hline & No Formal Education & $261(73.3)$ & $306(18.7)$ & ref $f^{\beta}$ & ref ${ }^{\beta}$ \\
\hline \multirow[t]{2}{*}{ Production system } & Nomadic Pastoralist & $272(88.3)$ & $286(23.3)$ & $24.7(17.2-36.3)$ & $8.6(3.6-20.2)$ \\
\hline & Mixed Farming & $36(11.7)$ & $939(76.7)$ & ref $f^{\beta}$ & ref $f^{\beta}$ \\
\hline \multirow[t]{2}{*}{ Drink unboiled milk } & Yes & $227(68.2)$ & $233(14.6)$ & $12.5(9.6-16.4)$ & $2.8(1.4-5.3)$ \\
\hline & No & 106 (31.8) & $1364(85.4)$ & ref $f^{\beta}$ & $r e f^{\beta}$ \\
\hline \multirow[t]{2}{*}{ Drink raw blood } & Yes & $88(24.6)$ & $88(5.3)$ & $5.8(4.2-8.0)$ & $1.1(0.6-1.8)$ \\
\hline & No & $269(75.4)$ & $1559(94.7)$ & ref $f^{\beta}$ & ref $f^{\beta}$ \\
\hline \multirow[t]{2}{*}{ Assist in animal birthing } & Yes & $107(42.1)$ & $170(16.7)$ & $3.6(2.7-4.9)$ & $0.9(0.5-1.4)$ \\
\hline & No & $147(57.9)$ & $845(83.3)$ & ref ${ }^{\beta}$ & ref $f^{\beta}$ \\
\hline \multirow[t]{2}{*}{ Handle raw hides } & Yes & $97(27.2)$ & $148(9.0)$ & $3.8(2.8-5.0)$ & $1.0(0.6-1.6)$ \\
\hline & No & $260(72.8)$ & $1499(91.0)$ & ref ${ }^{\beta}$ & ref $f^{\beta}$ \\
\hline \multirow[t]{2}{*}{ Clean barns } & Yes & $240(67.2)$ & 909 (55.2) & $1.7(1.3-2.1)$ & $1.0(0.5-1.2)$ \\
\hline & No & 117 (32.8) & 738 (44.8) & ref $f^{\beta}$ & ref $f^{\beta}$ \\
\hline
\end{tabular}


Our study found that two-thirds of the pastoralists had no formal education whereas almost all (92\%) of the mixed farmers had at least primary school education, including almost half that had secondary school education or higher. The low level of formal education among pastoralists, who typically live in expansive and sparsely populated remote semi-arid and arid lands of subSaharan Africa, when compared to other communities living in more developed and agriculturally productive regions, is associated with underdevelopment and poor infrastructures, and the occupation and lifestyle of pastoralists [19-21]. Despite this disparity in education, our study found the two livestock-owning communities with comparable knowledge levels of brucellosis disease, including a moderate to high knowledge of its existence and its effects on humans and low knowledge such as mechanisms of animal-to-human transmission and prevention and control measures. This finding is in agreement with other studies showing there is significant knowledge of common endemic zoonotic disease including brucellosis, echinococcosis, and rabies exists among nomadic pastoralists despite the lack of formal education [22].

The question is why pastoralists engage in risky practices given their knowledge level is similar to mixed farmers. One possibility is that nomadic pastoralists, perhaps because of low levels of formal education and representation in national leadership, distrust the government health services, resulting in low receptiveness to public health and animal health education on disease prevention and control [22]. This is unlikely because our experience during field studies and vaccination campaigns show comparable reception of among all communities. A more plausible explanation is that lack of other sources of livelihood and occupations, apart from rearing livestock in these arid lands, leaves pastoralists with no choice but to engage in risky practices in the course of their interactions with livestock - perhaps even when they know the associated risks. Our interactions with nomadic pastoralists including some with education and knowledge of risk factors of brucellosis revealed that they engage in risky practices because of culture. Social studies to understand why people engage in risky practices such as commercial sex workers engaging in unsafe sex, drug users, and youth engaging in texting while driving identified economic insecurity and culture as possible reasons [23-26]. The studies among drug users involved in risky income generation showed that almost half of them would continue the risky practices even if they went off drugs but remained economically insecure [23]. The primary occupation of nomadic pastoralists is to herd livestock and use these and their products including milk, meat, fur, hides, leather and manure for their livelihood and socio-economic advancement. They routinely give extra care to pregnant livestock, which are typically kept near pasture areas to reduce the long treks that other animals undertake and including assisting them with birth and management of the newborn animals. In addition, they routinely drink raw blood and unboiled milk obtained for survival during their movement across the arid lands [9, 27, 28]. Nomadic pastoralists believe that unboiled camel milk has better taste and it possesses medicinal value including aphrodisiac properties [27-31]. In addition, they engaged in skinning and therefore handling raw hides because of the high market value of camel leather and hair [32]. Since our study also found that lack of formal education was an important risk factor associated with increased risk of brucellosis infection, we envision that promoting formal education among the pastoralists would result in improved economic opportunities and reduction in risky practices as has been observed in other studies [33, 34].

Previous findings showed over 65\% household prevalence of brucellosis among the nomadic pastoralist communities of Marsabit County, which was 12-fold higher than other regions of the country [10]. The findings of our current study suggest that health education should emphasize risky cultural practices and accompanied by increased formal education and economic renaissance. It is likely the recent introduction of a devolved government in Kenya, which increased public participation and resource allocation to such marginalized areas will begin to turn the tide of such endemic zoonotic diseases. However, a more effective approach should be to promote formal education and development and implement a prevention and control strategy targeting reduction of the disease in both livestock through routine vaccination, and public education among humans to curb the risky practices we identified.

This study had some limitations. First, the exclusion of children below 5 years of age limits the generalizability of our data to the entire population. Our determination of risky practices was based on interviews, which could likely introduce information bias with participants giving responses they consider favorable. We think that this possible bias was minimal based on findings of the key informant interviews on the prevalence of the practices in the communities.

The little knowledge of how brucellosis is transmitted to humans and among animals suggest that more public education on the disease would be useful, while at the same time developing behavior change communication strategies for different communities is critical. In addition, there is need for collaboration between the veterinary and public health professionals through the one health approach in the provision of health education and information including symptoms, transmission pathways and prevention of brucellosis at community level to reduce disease prevalence. 


\section{Conclusions}

Our findings show that despite comparable levels of knowledge of brucellosis disease by both nomadic pastoralists and mixed farmers, over two-thirds of nomadic pastoralists engaged in at least one of four key risky practices including consumption of unboiled milk and raw blood, assisting with animal birth and handling raw hides. We also found a strong link between these practices and Brucella spp. seropositivity, including a nearly 3-fold higher odds of seropositivity for people who consumed unboiled milk. We argue that nomadic pastoralists are likely to engage in risky practices which promote Brucella spp. infection probably related to occupation and culture, despite having significant knowledge of the disease.

\section{Supplementary information}

Supplementary information accompanies this paper at https://doi.org/10. 1186/s12889-020-8362-0.

Additional file 1. STROBE Checklist.

\section{Abbreviations}

aOR: Adjusted Odds Ratio; Cl: Confidence Interval; cOR: Crude Odds Ratio; IgG: Immunoglobulin G

\section{Acknowledgments}

We thank the study staff involved in collecting data and specimens, and the Government of Kenya sectors including Ministry of Health and Ministry of Agriculture, Livestock, Fisheries and Irrigation, and the Marsabit and Kiambu County governments for their support during the study.

\section{Disclaimer}

The findings and conclusions in this manuscript are those of the authors and do not necessarily represent the official position of the Defense Threat Reduction Agency or US Centers for Disease Control and Prevention.

\section{Authors' contributions}

Conceptualization and design of the study: EMO, KN, SM, PM, EO, MM, AB. Sample and data collection: EMO, KN, SO, DM, EO, PM, AB. Laboratory testing: SO, KN. Data analysis: MW, SM, EMO, DM, BB, IN. Writing draft manuscript: KN, EMO, EO, SM, IN. Reviewing and editing manuscript: KN, MW, $\mathrm{EMO}, \mathrm{SO}, \mathrm{DM}, \mathrm{AB}, \mathrm{MM}, \mathrm{EO}, \mathrm{SM}, \mathrm{BB}, \mathrm{PM}, \mathrm{IN}$. All authors read and approved the final manuscript.

\section{Funding}

This study was supported by funding from the Defense Threat Reduction Agency of the U.S. Department of Defense. The funders had no role in study design, data collection and analysis, decision to publish, or preparation of the manuscript.

\section{Availability of data and materials}

The questionnaire, datasets used and/or analysed during the current study are available from the corresponding author on reasonable request.

\section{Ethics approval and consent to participate}

The study was approved by the Kenya Medical Research Institute Scientific Ethical Review Committee (No. 2193) and Centers for Disease Control and Prevention Institutional Review Board and all participants gave written informed consent before enrolment.

\section{Consent for publication}

Not applicable.

\section{Competing interests}

The authors declare that they have no competing interests.

\section{Author details}

${ }^{1}$ Washington State University Global Health Program, Washington State University, Nairobi, Kenya. ${ }^{2}$ Jaramogi Oginga Odinga University of Science and Technology, Bondo, Kenya. ${ }^{3}$ Kenya Ministry of Agriculture and Fisheries, Nairobi, Kenya. ${ }^{4}$ Center for Global Health Research, Kenya Medical Research Institute, Nairobi, Kenya. ${ }^{5}$ United Nations Food and Agriculture Organization-Kenya Office, Nairobi, Kenya. ${ }^{6}$ International Livestock Research Institute, Nairobi, Kenya. ${ }^{7}$ Division of Global Health Protection, Centers for Disease Control and Prevention-Kenya, Nairobi, Kenya.

Received: 29 June 2019 Accepted: 17 February 2020

Published online: 24 February 2020

\section{References}

1. Corbel M. Brucellosis in humans and animals. Geneva: World Health Organization, Food and Agriculture Organization of the United Nations, World Organization for Animal Health; 2006.

2. Malik G. A clinical study of brucellosis in adults in the Asir region of southern Saudi Arabia. Am J Trop Med Hyg. 1997;56:375-7.

3. Dean A, Crump L, Greter H, Hattendorf J, Schelling E, Zinsstag J. Clinical manifestations of human brucellosis: a systematic review and meta-analysis. PLoS Negl Trop Dis. 2012;6(12):e1929.

4. Solera J, Martinez-Alfaro E, Espinosa A. Recognition and optimum treatment of brucellosis. Drugs. 1997;53:245-56.

5. Mcdermott JJ, Grace D, Zinsstag J. Economics of brucellosis impact and control in low-income countries. Rev Sci Tech. 2013;32:249-61.

6. Schelling E, Diguimbaye C, Daoud S, Nicolet J, Boerlin P, Tanner M, et al. Brucellosis and Q-fever seroprevalences of nomadic pastoralists and their livestock in Chad. Prev Vet Med. 2003;61(4):279-93.

7. Hegazy Y, Elmonir W, Abdel-Hamid NH, Elbauomy EM. Seroprevalence and "Knowledge, Attitudes and Practices" (KAPs) survey of endemic ovine brucellosis in Egypt. Acta Vet Scand. 2016;58:1.

8. Musallam II, Abo-Shehada MN, Guitian J. Knowledge, attitudes, and practices associated with brucellosis in livestock owners in Jordan. Am J Trop Med Hyg. 2015;93(6):1148-55.

9. Muflihanah $H$, Hatta M, Rood E, Scheelbeek P, Abdoel TH, Smits HL. Brucellosis seroprevalence in Bali cattle with reproductive failure in South Sulawesi and Brucella abortus biovar 1 genotypes in the Eastern Indonesian archipelago. BMC Vet Res. 2013;9:233.

10. Osoro EM, Munyua P, Omulo S, Ogola E, Ade F, Mbatha P, et al. Strong association between human and animal brucella seropositivity in a linked study in Kenya, 2012-2013. Am J Trop Med Hyg. 2015;93:224-31.

11. Jelastopulu E, Bikas C, Petropoulos C, Leotsinidis M. Incidence of human brucellosis in a rural area in Western Greece after the implementation of a vaccination programme against animal brucellosis. BMC Public Health. 2008; $8(1): 241$.

12. Arif S, Thomson PC, Hernandez-Jover M, McGill DM, Warriach HM, Heller J. Knowledge, attitudes and practices (KAP) relating to brucellosis in smallholder dairy farmers in two provinces in Pakistan. PLoS One. 2017; 12(3):e0173365

13. Kansiime C, Atuyambe LM, Asiimwe BB, Mugisha A, Mugisha S, Guma V, et al. Community perceptions on integrating animal vaccination and health education by veterinary and public health workers in the prevention of brucellosis among pastoral communities of south western Uganda. PLoS One. 2015;10(7):e0132206.

14. Brouqui P, Benkouiten S, Gautret P, Gaillard C, Parola P. Camel milkassociated infection risk perception and knowledge in French Hajj pilgrims. Vector Borne Zoonotic Dis. 2013;13(6):425-7.

15. Legesse M, Medhin G, Bayissa M, Mamo G. Knowledge and perception of pastoral community members about brucellosis as a cause of abortion in animals and its zoonotic importance in Amibara district, Afar Region, Ethiopia. PLoS One. 2018;13(11):e0206457.

16. County Government of Kiambu. County integrated development plan 20182022. Nairobi: County Government of Kiambu; 2018.

17. County Government of Marsabit. Second county integrated development plan, 2018-2022. Marsabit: County Government of Marsabit; 2018.

18. R Development Core Team. R: a language and environment for statistical computing. 2017. https://www.r-project.org/. 
19. Sifuna DN. Increasing access and participation of pastoralist communities in primary education in Kenya. Int Rev Educ. 2005;52:499-516

20. Bishop E. Schooling and pastoralists livelihood: a Tanzanian case study: PhD Thesis, Univ of London; 2007. http://discovery.ucl.ac.uk/1444027/1/U591306.pdf

21. Food and Agriculture Organization of the United Nations (FAO). Educating nomadic herders out of poverty?: culture, education and poverty in Turkana and Karamoja. 2001

22. Zinsstag J, Ould Taleb M, Craig PS. Health of nomadic pastoralists: new approaches towards equity effectiveness: editorial. Trop Med Int Health. 2006;11(5):565-8.

23. Cheng T, Kerr T, Small W, Nguyen P, Wood E, DeBeck K. High prevalence of risky income generation among street-involved youth in a Canadian setting. Int J Drug Policy. 2016;28:91-7.

24. Olsen EO, Shults RA, Eaton DK. Texting while driving and other risky motor vehicle behaviors among US high school students. Pediatrics. 2013;131(6): e1708-15.

25. James LM, Strom TQ, Leskela J. Risk-taking behaviors and impulsivity among veterans with and without PTSD and mild TBI. Mil Med. 2014;179(4):357-63.

26. Kopetz C, Pickover A, Magidson JF, Richards JM, Iwamoto D, Lejuez CW. Gender and social rejection as risk factors for engaging in risky sexual behavior among crack/cocaine users. Prev Sci. 2014;15:376-84.

27. van Straten M, Bercovich Z, Zia-Ur-Rahman. The diagnosis of brucellosis in female camels (Camelus dromedarius) using the milk ring test and milk ELISA: a pilot study. J Camel Pract Res. 1997:4(2):165-8.

28. Gwida M, El-Gohary A, Melzer F, Khan I, Rosler U, Neubauer H, et al. Brucellosis in camels. Res Vet Sci. 2012:92:351-5.

29. Seifu Eyassu. Handling, preservation and utilization of camel milk and camel milk products in Shinile and Jijiga Zones, eastern Ethiopia. Livest Res Rural Dev. 2007;19. Cali, Colombia. http://www.Irrd.org//rrd19/6/seif19086.htm.

30. Knoess K. The milch dromedary. The camelid: an all-purpose animal. In: Proceedings of Khartoum workshop on Camel, December 1979. Uppsala; 1984. p. 176-95.

31. Agrawal RP, Jain S, Shah S, Chopra A, Agarwal V. Effect of camel milk on glycemic control and insulin requirement in patients with type 1 diabetes: 2-years randomized controlled trial. Eur J Clin Nutr. 2011;65(9):1048-52.

32. Wernery U. Camel milk - new observations. In: Proceedings of the International Camel Conference "Recent trends in Camelids research and Future strategies for saving Camels". Rajasthan, India; 2007. p. 200-4

33. Omadang L, Chamai M, Othieno E, Okwi A, Inangolet FO, Ejobi F, et al. Knowledge, attitudes and practices towards cystic echinococcosis in livestock among selected pastoral and agro-pastoral communities in Uganda. Trop Anim Health Prod. 2018;50(1):11-7.

34. Alhaji NB, Babalobi OO, Isola TO. A quantitative exploration of nomadic pastoralists' knowledge and practices towards Rift Valley fever in Niger State, North-central Nigeria: The associated socio-cultural drivers. One Heal. 2018:6:16-22

\section{Publisher's Note}

Springer Nature remains neutral with regard to jurisdictional claims in published maps and institutional affiliations.

Ready to submit your research? Choose BMC and benefit from:

- fast, convenient online submission

- thorough peer review by experienced researchers in your field

- rapid publication on acceptance

- support for research data, including large and complex data types

- gold Open Access which fosters wider collaboration and increased citations

- maximum visibility for your research: over $100 \mathrm{M}$ website views per year

At BMC, research is always in progress.

Learn more biomedcentral.com/submissions 